\title{
Centocor staggered by poor clinical results
}

Washington. Centocor, Inc. of Malvern, Pennsylvania, suffered a serious setback last week when an interim analysis of the company's clinical data revealed an unexpectedly high number of deaths in a group of patients being treated with the company's leading product, Centoxin (or HA-1 A). These adverse findings have forced Centocor, founded in 1979, to stop its phase III clinical trial in the United States and to suspend sales of the drug in Europe pending further analysis.

Centocor's share price plummeted after the announcement, falling 62 per cent to $\$ 6.625$. Many analysts now speculate that Centoxin will never be approved in the United States and that Centocor, at one time considered to be among the world's leading biotechnology companies, will be forced to cut its losses with Centoxin - a human monoclonal antibody designed for the treatment of Gram-negative sepsis and septic shock.

Centoxin is thought to act by binding specifically to the lipid-A component of endotoxin, the toxin released by Gram-negative bacteria. Company officials remain tight-lipped about the number of people who have died, saying that further analysis will be necessary to determine the higher mortality among patients treated with Centoxin who did not have Gram-negative bacteraemia (the group in whom Centoxin has no proven benefit) compared with patients in the same group who received a placebo.

"On the basis of our information to date, we do not believe that HA-1A is unsafe", says David Holveck, president and chief executive officer of Centocor. "The statistical requirement for a suspension of the US trial was conservative, but it was Centocor's responsibility to suspend all use of HA-1 A if there was any hint of trouble", he says.

The best news for Centocor would be that it was a statistical anomaly caused by a flaw in the design of the clinical trial. However, if it turns out to be a problem with a particular batch of drugs or, worse still, something wrong with the drug itself, the drug may be finished. "Even if it is something that can be corrected, people remember that there was a problem, they don't necessarily remember the explanation", says David Stone, a stock analyst with Cowen and Co.

At the very least, Centocor is expected to dispense with its almost 200-person US salesforce. Jeffrey Casdin, a stock analyst with Oppenheimer \& Co., says that the company may also be forced to sell off some of its excess manufacturing capacity (the company has three manufacturing plants) and lay off many of its clinical and regulatory staff.

Although there is an urgent medical need for new therapies against sepsis (there are about 400,000 cases a year in the United States and the numbers are increasing), some clinicians have questioned the effectiveness of Centoxin and Xomen-E5, a rival mouse monoclonal antibody product produced by Xoma Corporation of Berkeley, California.

The warning signs concerning Centoxin appeared in 1991 when several letters critical of Centocor's earlier clinical trial data on Centoxin were published (New Engl.J.Med 325, 279-283; 1991). An increase in mortality among patients without Gram-negative bacteraemia in the group receiving Centoxin was also evident in Centocor's earlier phase III clinical trial (New Engl. $J$. Med. 324, 429-436; 1991), according to Craig Tanio and Harold Feldman of the University of Pennsylvania. They wrote that this trend toward increased mortality in this group of patients "raises the question of whether HA-1A may be seriously toxic in a large proportion of patients presenting with sepsis".

Other clinicians argued that lack of a quick diagnostic test to differentiate between Gram-negative and Gram-positive infections would result in the use of Centoxin in many patients for whom it has no proven benefit. Some analysts argue that the writing was on the wall for Centocor last April when the US Food and Drug Administration told the company that there was insufficient evidence to establish the efficacy of Centoxin and that a further phase III clinical trial must be undertaken.

Investors became disenchanted and the company's stock price dropped. Some investors were wooed back when, in July, Eli Lilly \& Co. of Indianapolis, Indiana, invested $\$ 100$ million in return for the distribution rights to Centoxin and an option to obtain the rights to CentoRx, a cardiovascular agent.

Even if the US clinical trial was to be resumed, some analysts feel that the antiendotoxin approach being taken by Centocor and Xoma could lose out to more broadly acting therapies that do not rely on knowing that the patient's infection is due to Gramnegative or Gram-positive bacteria. Antril, a recombinant interleukin-1 receptor antagonist being developed by Synergen, Inc. of Boulder, Colorado, appears to work against both types of infections. Diane Gershon

\section{WHO vote upsets Western nations}

Tokyo, Washington \& London. A sense of gloom has descended on the Geneva headquarters of the World Health Organization (WHO) following the reappointment last week of Japan's Hiroshi Nakajima as director general. The United States and European nations lobbied hard to replace Nakajima, whose management they have strongly criticized. Japanese officials, on the other hand, are elated because they see his re-election as an example of the country's growing presence in the international arena.

The 64-year-old pharmacologist, who joined WHO in 1973 and was appointed director general in 1988, is seen as having provoked the departure in 1990 of Jonathan Mann, the highly respected leader of WHO's AIDS programme (see Nature 344, 283; 1990). And Donald Henderson, associate director for life sciences at the US Office of Science and Technology Policy and a former WHO official, says there has been "no vision and no progress" during Nakajima's first term.

Nakajima won last week's election by a vote of 18-13 over Mohammed Abdelmoumene of Algeria, the former deputy director general of WHO. In yet another example of what Western officials see as Nakajima's poor management style, Nakajima fired Abdelmoumene last August for "disloyalty" when he discovered the Algerian was running against him.

Japan put heavy pressure on developing nations to support Nakajima's re-election.
In December, the New York Times cited an internal US State Department report saying that the Japanese government had threatened to slash imports of coffee from Jamaica and marine products from the Maldives if they did not vote for Nakajima. Another rumour circulated that Japan would reduce its large voluntary contribution to WHO, now $\$ 14$ million a year, if Nakajima were defeated. These accusations were flatly denied by Japanese foreign ministry officials, who in turn saw Western opposition to Nakajima as "racist".

Japan's foreign minister, Michio Watanabe, welcomed Nakajima's reappointment and Yuya Niwa, Minister of Health and Welfare, attributed the result to "the fair evaluation of Mr Nakajima's ability and performance as director general".

But while Japanese officials celebrate, the mood in Geneva and Western capitals is grim. "Nakajima's management style threatens to derail WHO's main function of providing an international umbrella for important joint projects among countries that would be very difficult to pull off on a bilateral basis", says Henderson. British medical scientists are concerned that Western governments may withdraw their support for WHO's research programmes much as they did with UNESCO in the 1980s after continued criticism of its management.

David Swinbanks, Jeffrey Mervis

\& David Dickson 